\title{
FUNGSI LEGISLASI MAJELIS TINGGI DI INDONESIA DAN JERMAN: PERBANDINGAN ANTARA DPD DENGAN BUNDESRAT
} \author{
Comparison Between DPD and Bundesrat) \\ Abdurrachman Satrio \\ Fakultas Hukum Universitas Padjadjaran \\ Jl. Dipatiukur No. 35, Bandung \\ Email: abdurrachmanmarley@gmail.com
}

(Legislative Function of Upper House in Indonesia and Germany:

Naskah diterima: 5 Agustus 2015; revisi: 25 November 2015; disetujui: 2 Desember 2015

\begin{abstract}
Abstrak
Dinamika politik legislasi di tingkat nasional saat ini cenderung meminggirkan kepentingan daerah dan lebih mendahulukan kepentingan politik. Menurut penulis salah satu alasannya disebabkan karena Dewan Perwakilan Daerah (DPD) sebagai majelis tinggi dan representasi teritorial di tingkat nasional dalam menjalankan fungsinya yang utama yaitu fungsi legislasi tidak memiliki kewenangan yang kuat, terutama bila dibandingkan dengan DPR sebagai majelis rendah dan representasi politik. Oleh karena itu, penelitian ini mencoba menemukan dasar argumentasi perlunya penguatan terhadap kewenangan konstitusional DPD sebagai majelis tinggi dalam menjalankan fungsi legislasi dengan membandingkan fungsi legislasi yang dimiliki DPD dengan Bundesrat di Jerman sebagai majelis tinggi lainnya yang juga berperan sebagai representasi teritorial di tingkat nasional. Penelitian ini bersifat yuridis normatif dengan menitikberatkan adanya kesenjangan antara harapan (das sollen) dan kenyataan (das sein), melalui studi perbandingan akan ditemukan persamaan-persamaan (similiarities) serta perbedaan (contrast) di antara keduanya. Dari perbandingan tersebut terlihat bahwa Bundesrat memiliki fungsi legislasi yang jauh lebih kuat dibandingkan DPD, padahal secara teoritis seharusnya DPD memiliki fungsi legislasi yang lebih kuat sebagai majelis tinggi dibandingkan dengan Bundesrat.
\end{abstract}

Kata Kunci: Bundesrat, majelis tinggi, fungsi legislasi

\section{Abstract}

The dynamic-political process of legislation in national level at this time, tends to ignore a local interest and give precedence to political interest. In my opinion one of the reason is because Dewan Perwakilan Daerah (DPD) as a territorial representative at national level in order to run the main function that is legislative function has no powerful authority, compare to DPR as a lower house and as political representative. That's why, this research try to find basic argumentation the need to strengthen the constitutional authority of DPD as upper house to run legislative function by comparing with German upper house (Bundesrat) which has capacity as territorial representative in national scale. This research is conducted in normative-jurist method which focuses on the existence of expectation (das sollen) and reality (das sein), through this comparison it will be found the similarities and differences in those two. From this comparison we find that Bundesrat has a stronger legislative function than DPD well in fact, theoritically legislative function of DPD must be stronger as a upper house compares to Bundesrat.

Keywords: Bundesrat, upper house, legislative function 


\section{A. Pendahuluan}

Pada umumnya di dunia ini model-model sistem perwakilan terklasifikasi menjadi dua yaitu sistem perwakilan bikameral (dua kamar) dan sistem perwakilan unikameral (satu kamar). Namun kebanyakan negara-negara besar di dunia ini menganut sistem perwakilan dua kamar sebagaimana hal itu diungkapkan oleh C.F. Strong dalam bukunya bahwa "In the history of great states unicameral constitutionalism is a comparatively rare, and generally temporary, phenomenon, and bicameralism is characteristic of most important states today", ${ }^{1}$ sedangkan di negara-negara kecil yang memiliki luas wilayah lebih kecil dan memiliki populasi yang lebih sedikit umumnya memilih sistem perwakilan satu kamar. ${ }^{2}$ Meskipun besar atau kecilnya suatu negara mempengaruhi dipilihnya model sistem perwakilannya, akan tetapi dipilihnya sistem bikameral itu sendiri tidak dipengaruhi oleh landasan bernegara tertentu, bentuk negara, bentuk pemerintahan, atau sistem pemerintahan tertentu, sebab tiap negara mempunyai pertimbangannya masing-masing. ${ }^{3}$ Contohnya adalah Inggris yang menganut bentuk pemerintahan kerajaan, bentuk negara kesatuan, dan memiliki sistem pemerintahan parlementer menjalankan sistem bikameral dengan pertimbangan kesejarahan. Berbeda dengan Inggris, Amerika Serikat yang menganut bentuk pemerintahan republik, bentuk negara federal, dan menganut sistem pemerintahan presidensil memilih sistem bikameral atas hasil kompromi antara negara bagian yang berpenduduk banyak dengan yang berpenduduk sedikit. ${ }^{4}$

Meski tiap negara memiliki pertimbangan masing-masing dalam menganut sistem bikameral, namun pada dasarnya kunci utama dalam setiap sistem bikameral adalah adanya perbedaan keterwakilan antara kedua kamar yakni majelis tinggi dengan majelis rendah, ${ }^{5}$ sebab sebagaimana dikemukakan oleh Waldron apabila tidak terdapat perbedaan keterwakilan diantara keduanya maka keberadaan suatu sistem bikameral menjadi sia-sia saja. ${ }^{6}$ Dalam setiap sistem bikameral itu sendiri pada umumnya terdapat suatu kesamaan dimana majelis rendah atau kamar pertama pengisian keanggotaannya dipilih secara langsung dengan berdasarkan pada populasi dan merupakan keterwakilan politik, sehingga umumnya majelis rendah memiliki kekuasaan yang lebih dominan dibanding kamar kedua atau majelis 
tinggi. ${ }^{7}$ Sebaliknya majelis tinggi secara umum amat beragam baik dalam keterwakilannya maupun model rekrutmen atau pengisian keanggotaannya. ${ }^{8}$

Di Indonesia pada saat dilakukannya amandemen Undang-Undang Dasar (UUD) 1945 sebanyak empat kali pada tahun 1999-2002, muncul gagasan untuk mengubah model sistem perwakilan Indonesia yang terdiri dari Majelis Permusyawaratan Rakyat (MPR), dimana MPR tersebut terdiri dari tiga unsur yaitu Dewan Perwakilan Rakyat (DPR), Utusan Daerah, dan Utusan Golongan menjadi sistem perwakilan bikameral yang terdiri dari DPR sebagai majelis rendah dan cerminan representasi politik, dengan DPD sebagai majelis tinggi dan cerminan prinsip representasi regional. ${ }^{9}$ Keinginan untuk menganut sistem dua kamar dengan DPD sebagai kamar kedua dan representasi regional sebagaimana diutarakan oleh Bagir Manan didasari oleh beberapa pertimbangan yaitu: ${ }^{10}$

a. Sistem dua kamar merupakan suatu mekanisme check and balances antara kamar-kamar dalam satu badan perwakilan.

b. Penyederhanaan sistem badan perwakilan tingkat pusat, sehingga hanya ada satu badan perwakilan tingkat pusat yang terdiri dari dua unsur yaitu unsur yang mewakili seluruh rakyat dan unsur yang mewakili daerah. c. Wakil daerah menjadi bagian dari pelaksanaan fungsi parlemen (membentuk undang-undang, mengawasi pemerintah, menetapkan APBN, dan lain-lain). Dengan demikian diharapkan segala kepentingan daerah akan terintegrasi dalam kegiatan parlemen.

d. Sistem dua kamar akan lebih produktif karena segala tugas dan wewenang dapat dilakukan setiap unsur.

Namun sayangnya selama jalannya pembahasan di MPR, ide bikameralisme atau sistem perwakilan dua kamar tersebut mendapatkan tantangan yang sangat kuat dari kalangan konservatif yang menolak perubahan UUD 1945, sehingga hasilnya seperti yang kita lihat saat ini merupakan hasil kompromi politik dari kepentingan-kepentingan politik yang bertentangan selama proses pembahasan berlangsung. ${ }^{11}$ Akibatnya rumusan yang ada saat ini tidak dapat disebut bikameral sama sekali karena lemahnya fungsi legislasi yang dimiliki oleh DPD, ${ }^{12}$ padahal apabila berbicara mengenai fungsi lembaga perwakilan dalam suatu negara demokratis maka fungsi yang paling utama adalah fungsi pembentukan undang-undang (fungsi legislasi), sebab mandat yang didapat dari rakyat yang memilih membuat suatu

7 Lihat Arend Lijphart, Pattern of Majoritarian and Consensus Government in Twenty-One Country, (New Haven and London: Yale University Press, 1984), hlm. 91; Lihat juga Alan R. Ball, Modern Politics and Government (Fourth Edition), (London: Macmillan Education, 1988), hlm. 149.

8 TA. Legowo, Keterwakilan Politik dan Tipe Parlemen dalam Perspektif Teoritis dan Sejarah, dalam Gagasan Amandemen UUD 1945 Suatu Rekomendasi, disusun oleh Mohammad Fajrul Falaakh (ed), (Jakarta: Komisi Hukum Nasional RI, 2008), hlm. 223.

9 Jimly Asshiddiqie, Perkembangan dan Konsolidasi Lembaga Negara Pasca Reformasi, (Jakarta: Sekjen dan Kepaniteraan Mahkamah Konstitusi Republik Indonesia, 2006), hlm. 140.

10 Bagir Manan, Op. Cit, hlm. 59.

11 Mahfud MD, Perdebatan Hukum Tata Negara Pasca Amandemen Konstitusi, (Jakarta: Rajawali Pers, 2011), hlm. 69.

12 Jimly Asshiddiqie, Op. Cit, hlm. 140. 
lembaga perwakilan diserahi tanggungjawab untuk mengatur di wilayah-wilayah publik. ${ }^{13}$

Karena lemahnya fungsi legislasi DPD sebagai majelis tinggi atau kamar kedua yang berperan sebagai representasi daerah di tingkat nasional tersebut, maka tak mengherankan apabila dinamika politik legislasi di tingkat nasional yang memiliki dampak besar terhadap daerah cenderung bersifat reaksioner dan tanpa suatu perencanaan yang matang karena lebih mengutamakan kepentingan politis serta meminggirkan kepentingan daerah, contohnya dapat dilihat dari diundangkannya UndangUndang (UU) Nomor 22 Tahun 2014 tentang Pemilihan Gubernur, Bupati, dan Walikota setahun yang lalu, yang mana UU tersebut mengganti mekanisme pemilihan kepala daerah secara langsung oleh rakyat menjadi tidak langsung melalui DPRD. Sebenarnya tidak terdapat suatu alasan yang kuat mengapa mekanisme pemilihan kepala daerah tersebut diganti, karena sesungguhnya penggantian mekanisme pemilihan kepala daerah lewat UU tersebut merupakan suatu akrobat politik dari partai-partai pendukung Koalisi Merah Putih (KMP) yang terdapat di DPR. ${ }^{14}$ Hasilnya pun tak mengherankan bila kemudian UU Nomor 22 Tahun 2014 mendapatkan penolakan yang luas dari berbagai elemen masyarakat. ${ }^{15}$ Penolakan dan tekanan yang luas dari masyarakat tersebut akhirnya menyebabkan pemerintah terpaksa bertindak cepat dengan mengeluarkan Peraturan Pemerintah Pengganti Undang-
Undang (Perpu) Nomor 1 Tahun 2014 tentang Pemilihan Gubernur, Bupati, dan Wali Kota yang isinya mengembalikan mekanisme pemilihan kepala daerah menjadi secara langsung oleh rakyat. $^{16}$

Berdasarkan contoh tersebut, maka terlihat bahwa saat ini kepentingan daerah cenderung terpinggirkan oleh kepentingan politik dalam dinamika politik legislasi di tingkat nasional yang salah satu sebabnya dikarenakan lemahnya fungsi legislasi yang dimiliki DPD sebagai majelis tinggi yang merupakan representasi daerah, oleh karena itulah agar kedepannya dinamika politik legislasi di tingkat nasional tidak bersifat reaksioner dan cenderung mementingkan kepentingan politik maka dalam artikel ini penulis mencoba mengemukakan argumentasi mengenai perlunya penguatan terhadap fungsi legislasi DPD yang terdapat di UUD 1945 dengan membandingkan fungsi legislasi yang dimiliki oleh DPD tersebut dengan fungsi legislasi dari majelis tinggi lainnya yang ada di dunia. Dalam pada itu penulis memilih membandingkan fungsi legislasi DPD dengan fungsi legislasi dari Bundesrat sebagai majelis tinggi yang terdapat di Jerman, dimana penulis akan membandingkan fungsi legislasi dari dua majelis tinggi tersebut yang terdapat di masing-masing konstitusinya untuk menemukan perbedaan-perbedaan serta persamaan-persamaan yang terdapat diantara keduanya, yang mana nantinya perbandingan tersebut akan dikontekstualkan dan dijadikan dasar argumentasi mengenai 
perlunya penguatan konstitusional terhadap fungsi legislasi DPD agar nantinya DPD mampu mencapai tujuan ketika dibentuknya yaitu mengintegrasikan kepentingan daerah di tingkat nasional.

Oleh karena itulah, berdasarkan latar belakang tersebut maka dalam artikel ini terdapat tiga rumusan masalah yang perlu dijawab oleh penulis, yakni: (1) Bagaimana kedudukan dan fungsi legislasi dari DPD sebagai majelis tinggi di Indonesia? (2) Bagaimana kedudukan dan fungsi legislasi dari Bundesrat sebagai majelis tinggi di Jerman? Dan (3) Seperti apa perbandingan keduanya sebagai majelis tinggi?

\section{B. Metode Penelitian}

Penelitian ini merupakan penelitian yuridis normatif yaitu suatu metode yang menitikberatkan penelitian karena adanya kesenjangan antara harapan (das sollen) dan kenyataan (das sein). Metode penelitian yuridis normatif dilakukan melalui studi kepustakaan yang menelaah data sekunder, baik yang berupa peraturan perundang-undangan maupun hasil penelitian, hasil pengkajian, dan referensi lain $^{17}$ serta pendapat ahli yang berkaitan dengan fungsi legislasi dan kedudukan majelis tinggi di Indonesia dengan Jerman. Kemudian berdasarkan data-data yang didapat tersebut dilakukan analisis kualitatif terhadap teori-teori mengenai fungsi legislasi dan majelis tinggi. Selanjutnya dianalisis bagaimana perbandingan antara teori dankonsep mengenai fungsi legislasi dari majelis tinggi yang terdapat di Indonesia dan di Jerman. Dari hasil analisis tersebut akan ditemukan persamaan-persamaan (similiarities) serta perbedaan (contrast) di antara keduanya, yang nantinya akan dirumuskan untuk membentuk bagaimana seharusnya fungsi legislasi yang ideal dari DPD di Indonesia.

\section{Pembahasan}

\section{Kedudukan dan Fungsi Legislasi DPD}

Sebagai lembaga yang merupakan representasi teritorial dalam tipologi sistem parlemen di Indonesia, maka boleh dikatakan bahwa pembentukan DPD dimaksudkan sebagai upaya institusionalisasi representasi teritorial dalam tipologi sistem parlemen kita, karena sebelumnya apabila kita kaji secara historis representasi teritorial telah terdapat dalam UUD 1945 sebelum amandemen yaitu dalam Utusan Daerah yang merupakan bagian dari MPR, hanya saja tidak dilembagakan. ${ }^{18}$ Namun sayangnya keinginan untuk menciptakan DPD sebagai kamar kedua yang berperan sebagai representasi teritorial justru menghasilkan parlemen bikameral yang memiliki watak timpang yang luar biasa. ${ }^{19} \mathrm{Hal}$ itu dapat dilihat dalam rumusan mengenai wewenang DPD sebagaimana terdapat dalam Pasal 22D UUD 1945 hanya terbatas terhadap hal-hal berikut:

a) DPD dapat mengajukan kepada DPR RUU yang berkaitan dengan:

Otonomi daerah, hubungan pusat dan daerah, pembentukan pemekaran serta penggabungan daerah, pengelolaan sumber

\footnotetext{
17 Ronni Hanitijo Soemitro, Metode Penelitian Hukun dan Jurimetri, (Jakarta: Ghalia Indonesia, 1998), hlm. 10.

18 Mohammad Fajrul Falakh, "Susunan dan Kedudukan DPD", dalam DPD dalam Sistem Ketatanegaraan Republik Indonesia, disusun oleh Janedri M. Gaffar dkk (eds), (Jakarta: Sekertariat Jenderal MPR, 2003), hlm. 54.

19 Ibid.
} 
daya alam serta sumber daya ekonomi lainnya, serta yang berkaitan dengan perimbangan keuangan pusat dan daerah. ${ }^{20}$

b) DPD ikut membahas RUU yang berkaitan dengan:

Otonomi daerah, hubungan pusat dan daerah, pembentukan pemekaran serta penggabungan daerah, pengelolaan sumber daya alam serta sumber daya ekonomi lainnya, serta yang berkaitan dengan perimbangan keuangan pusat dan daerah. Serta memberi pertimbangan dalam RUU yang berkaitan dengan RAPBN, pajak, pendidikan, dan agama. ${ }^{21}$

c) DPD dapat melakukan pengawasan terhadap pelaksanaan UU mengenai:

Otonomi daerah, pembentukan pemekaran serta penggabungan daerah, hubungan pusat dan daerah, pengelolaan sumber daya alam dan sumber daya ekonomi lainnya, pelaksanaan APBN, pajak, pendidikan, dan agama. Hasil pemeriksaan tersebut kemudian disampaikan kepada DPR sebagai bahan pertimbangan untuk ditindaklanjuti. ${ }^{22}$ Berdasarkan wewenang-wewenang tersebut, tampak bahwa DPD sebagai lembaga legislatif tidak memiliki kedudukan yang kuat terutama dalam menjalankan fungsinya yang utama yaitu fungsi legislasi karena kewenangannya terbatas hanya sekedar mengajukan, membahas, dan mengawasi RUU tertentu, tidak sampai pada memutuskan apakah suatu RUU dapat menjadi UU, padahal bagaimanapun juga fungsi legislasi harus dilihat secara utuh yakni dimulai dari proses pengajuan sampai menyetujui sebuah rancangan undangundang. ${ }^{23}$ Sebetulnya ketimpangan fungsi legislasi antar kamar dalam sistem bikameral bukanlah sesuatu yang aneh, akan tetapi ketimpangan tersebut selalu diupayakan dengan memberi kompensasi kepada kamar lain yang lebih lemah, lazimnya majelis tinggi apabila tidak berhak mengajukan rancangan undang-undang diberi hak konstitusional untuk mengubah, mempertimbangkan, atau menolak rancangan undang-undang yang berasal dari majelis rendah. ${ }^{24}$ Sekiranya hak tersebut tidak ada, majelis tinggi diberikan hak konstitusional untuk menunda pengesahan rancangan undangundang. ${ }^{25}$

Sayangnya dalam kewenangannya yang diberikan oleh Pasal 22 UUD 1945 tersebut DPD tidak diberikan hak untuk mengubah dan menolak rancangan undang-undang, bahkan juga tidak diberikan hak untuk menunda pengesahan rancangan undang-undang yang telah disetujui bersama oleh DPR dan Presiden. Hal ini diperparah karena dalam praktiknya kedudukan DPD semakin "dilemahkan" dalam menjalankan fungsi legislasi, dimana hal itu dapat kita lihat dalam UU Nomor 27 Tahun 2009 tentang MPR, DPR, DPD, dan DPRD serta dalam UU Nomor 12 Tahun 2011 tentang Tata Cara Pembentukan Peraturan Perundang-Undangan karena kedua UU tersebut semakin melemahkan

Pasal 22D Ayat (1) UUD 1945.

Pasal 22D Ayat (2) UUD 1945.

Pasal 22D Ayat (3) UUD 1945.

Saldi Isra, Pergeseran Fungsi Legislasi (Menguatnya Model Legislasi Parlementer dalam Sistem Presidensial di Indonesia), (Jakarta: Rajawali Pers, 2013), hlm. 257.

$24 \quad$ Ibid, hlm. 258.

25 Ibid, hlm. 259. 
kewenangan DPD dalam mengajukan dan ikut membahas suatu rancangan undang-undang, meskipun akhirnya beberapa ketentuan dalam kedua UU tersebut dibatalkan oleh MK dalam Putusan Nomor 92/PUU-X/2012 yang mengembalikan kedudukan DPD sehingga dapat ikut membahas RUU bersama-sama dengan DPR dan Presiden, serta dipertegas kembali dalam UU 17 Tahun 2014 tentang MPR, DPR, DPD, dan DPRD yang merupakan tindak lanjut atas putusan Mahkamah Konstitusi (MK) tersebut. Akan tetapi tetap saja dalam praktiknya kedudukan DPD masih lemah dibandingkan DPR dalam menjalankan fungsi legislasi karena memang secara konstitusional Pasal 22 UUD 1945 telah membatasi kewenangan DPD.

Melihat lemahnya kedudukan DPD dalam fungsi legislasi tersebut, maka dapat dikatakan bahwa peran DPD hanya bersifat penunjang atau auxiliary terhadap fungsi DPR di bidang legislasi karena perannya hanya sebatas colegislator, ${ }^{26}$ bahkan Stephen Sherlock dengan tegas menyatakan bahwa berdasarkan kewenangannya tersebut DPD tidak dapat disebut sebagai majelis tinggi melainkan hanya suatu "badan pertimbangan" (advisory body) karena bahkan dalam area dimana DPD dapat memberikan pertimbangan (advice) pun juga dibatasi, ${ }^{27}$ tentu saja hal ini tampak tidak sebanding dengan persyaratan untuk menjadi anggota DPD yang lebih berat dari pada persyaratan untuk menjadi anggota
DPR, karena anggota DPD sebagaimana DPR sama-sama dipilih oleh rakyat, dimana daerah pemilihan untuk menjadi anggota DPD adalah provinsi dengan kuota masing-masing empat orang untuk tiap-tiap provinsi. Sedangkan untuk anggota DPR daerah pemilihannya meliputi wilayah di bawah provinsi seperti kabupaten dan kota dengan jumlah kursi yang lebih banyak dibanding DPD. Hal inilah yang menyebabkan pakar hukum tata negara Saldi Isra mengatakan bahwa gagasan untuk menciptakan lembaga perwakilan yang mampu menyalurkan aspirasi daerah telah gagal sebagaimana dikutip dalam tulisannya:

"With this limited power, DPD acts only as a sub-ordinate of DPR. Such a limitation gives rise to the opinion that the idea to create two chambers in order to provide a way for a new kind of representative from the regions to enter into the world of decisionmaking in the national level has failed. This failure will bring impact to the weakness of local political articulation in any stage of the national decision making process." 28

Gagalnya gagasan untuk menjadikan DPD sebagai lembaga perwakilan yang mampu mengintegrasikan kepentingan daerah tersebut menunjukan bahwa keberadaan suatu majelis tinggi tidaklah menjamin akan terciptanya suatu representasi regional yang efektif, ${ }^{29}$ sehingga saat ini muncul keinginan agar dilakukannya amandemen kelima terhadap UUD 1945, keinginan tersebut digulirkan oleh DPD, dengan didasari oleh dua alasan yakni:

26 Jimly Asshiddiqie, Op. Cit, hlm. 142.

27 Stephen Sherlock, Indonesia's Regional Representative Assembly: Democracy, Representation and the Regions, (Canberra: Center for Democratic Institutions, 2005), hlm. 9.

28 Saldi Isra, "The Role of the Second Chamber In the UK and Indonesia", (makalah merupakan tugas akhir ketika mengikuti Short Course "What Democracy Means" di University of Birmingham UK Januari-April 2006), diselenggarakan oleh Chevening Fellowship, UK, hlm. 6.

29 Lihat William B. Heller and Diana M. Branduse, "The Politics of Bicameralism", dalam The Oxford Handbook of Legislative Studies, disusun oleh Shane Martin (eds), (Oxford: Oxford University Press, 2014), hlm. 6. 
Pertama, ketidaksetaraan DPD dengan DPR. Dimana DPD hanya berperan sebagai pelengkap belaka dalam fungsi legislasi, dimana DPR boleh menunda atau tidak menerima pertimbangan atau usul DPR. Kedua, tata susunan DPR, DPD, dan MPR tidak mencerminkan cita-cita membentuk sistem dua kamar (bicameral), karena seharusnya dalam sistem dua kamar hanya terdapat satu badan perwakilan yang terdiri dari dua unsur perwakilan. ${ }^{30}$ Sayangnya gagasan untuk melakukan amandemen kelima terhadap sistem dua kamar dalam UUD 1945 tersebut gagal dilakukan karena kurangnya dukungan politik dari anggota-anggota DPR, yang menyebabkan tidak tercapainya kuorum 1/3 anggota MPR untuk mengajukan amandemen terhadap UUD 1945. Meskipun gagal namun adanya keinginan untuk melakukan amandemen kelima terhadap sistem perwakilan tersebut membuktikan bahwa terdapatnya banyak pandangan yang beranggapan bahwa perlunya DPD diberdayakan agar mampu mencapai tujuan ketika dibentuknya yakni mewadahi kepentingan dan aspirasi daerah, yang salah satunya adalah dengan memperkuat fungsi legislasinya. ${ }^{31}$

\section{Kedudukan dan Fungsi Legislasi Bundesrat}

Apabila dibandingkan dengan Jerman yang juga menganut sistem bikameral dengan Bundesrat sebagai majelis tinggi yang dibentuk dengan tujuan agar Lander (negara bagian) ikut berpartisipasi dalam kegiatan eksekutif dan legislatif yang dilakukan oleh pemerintahan federal, ${ }^{32}$ maka akan tampak bahwa kedudukan DPD amat lemah dibandingkan dengan kedudukan Bundesrat, sebab meskipun Konstitusi Jerman (Basic Law) tidak meletakan Bundesrat dalam posisi yang setara dengan Bundestag yang merupakan majelis rendah yang dipilih oleh rakyat dan merupakan parlemen tertinggi negara, namun Bundesrat memiliki hak untuk berpartisipasi dalam seluruh proses legislasi nasional, ${ }^{33}$ bahkan tidak hanya itu Bundesrat juga dapat ikut berpartisipasi dalam proses administrasi yang dilakukan oleh pemerintahan federal serta hal-hal yang menyangkut keanggotaan Jerman di Uni Eropa. ${ }^{34}$ Kuatnya kedudukan Bundesrat untuk ikut berpartisipasi dalam kegiatan eksekutif dan legislatif yang dilakukan oleh pemerintahan federal Jerman membuatnya menjadi majelis tinggi yang unik di dunia. Keunikan tersebut muncul lantaran keanggotaan Bundesrat diisi oleh anggota dari pemerintah Lander dan tidak 
dipilih langsung sebagaimana halnya anggota Bundestag, pemerintah Lander lah yang memutuskan siapa yang akan menjadi anggota Bundesrat (lazimnya menteri dari pemerintah Lander yang menjadi anggota dari Bundesrat) karena pengisian jabatannya tersebut, maka Bundesrat menjadi lembaga permanen tanpa periode jabatan lembaga legislatif pada umumnya, dan komposisi keanggotaannya hanya berubah setiap kali Lander melakukan pemilihan umum. Dengan kata lain para pemilih dalam pemilihan umum Lander hanya bisa mempengaruhi komposisi keanggotaan Bundesrat secara tidak langsung. ${ }^{35}$ Mekanisme pengisian keanggotaannya tersebutlah yang membuat Bundesrat menjadi majelis tinggi yang unik, sebab dengan keanggotaannya tersebut Bundesrat bukan hanya merupakan lembaga legislatif, tetapi sekaligus berperan sebagai eksekutif dari Lander, dan juga bukan merupakan bagian dari parlemen, karena hanya Bundestag lah parlemen di Jerman. ${ }^{36}$

Keunikan yang dimiliki oleh Bundesrat tersebut pada dasarnya didasari oleh alasan pembentukannya yang dimaksudkan untuk menjamin agar tidak terjadinya kontradiksi antara pemerintah pusat dan negara bagian. ${ }^{37}$ Sebab konsep federalisme yang dianut di Jerman sebagaimana dikemukakan oleh Matthias Platzeck mantan Presiden Bundesrat didasari oleh ide solidaritas, ${ }^{38}$ konsep ini sendiri di Jerman dikenal dengan istilah "Bundestreue" atau dalam bahasa Inggris dikenal sebagai "federal loyalty". Pada prinsipnya konsep ini bermakna bahwa hubungan antara federasi dan komponen-komponennya (yang dalam hal ini adalah Lander), serta antar masingmasing komponen dalam memenuhi urusannya haruslah bersifat timbal-balik dan mendukung persatuan dari federasi, ${ }^{39}$ sehingga amat penting untuk menjaga ikatan antara pemerintah pusat dengan Lander yang mana salah satu cara untuk menjaga ikatan tersebut adalah dengan dibentuknya Bundesrat.

Dalam menjalankan kewenangannya untuk berpartisipasi dalam proses legislasi Bundesrat memiliki hak untuk mengajukan rancangan undang-undang sebagaimana pemerintah federal Jerman dan Bundestag, namun kebanyakan rancangan undang-undang yang ada diajukan oleh pemerintah. Bagi rancangan undang-undang yang diajukan oleh pemerintah maka pemerintah harus mengajukan terlebih dahulu kepada Bundesrat sebagai majelis tinggi, yang mana Bundesrat memiliki waktu enam minggu untuk meresponnya. ${ }^{40}$ Apabila rancangan undang-undang diajukan oleh Bundestag, maka mereka harus mengajukan terlebih dahulu pada Bundesrat. ${ }^{41}$ Sedangkan apabila rancangan undang-undang diajukan oleh Bundesrat maka terlebih dahulu rancangan undang-undang tersebut harus diajukan kepada

\footnotetext{
35 Frank Feulner, "Menguatkan Demokrasi Perwakilan di Indonesia: Tinjauan Kritis Terhadap DPD”, Jurnal Jentera, Edisi 8 Tahun III, Maret (2005), hlm. 30.

36 Arthur Gunlicks, The Lander and German Federalism, (Manchester and New York: Manchester University Press, 2003), hlm. 339.

37 Konrad Reuter, The Bundesrat and The Federal System (14th Edition), (Berlin: Secretary General of the Bundesrat, 2009), hlm. 11.

38 Ibid. (Dengan frasa asli "The Basic Law takes the idea of federalism based on solidarity.")

39 Francois Venter, Op. Cit, hlm. 234.

40 Lihat Article 76 (2) (Chapter VII) German Basic Law

41 Lihat Article 77 (Chapter VII) German Basic Law mengenai prosedur legislatif.

42 Arthur Gunlicks, Op. Cit, hlm. 347.
} 
pemerintah federal, setelah itu barulah kepada Bundestag. ${ }^{42}$ Dalam pembahasan rancangan undang-undang yang umumnya diajukan pemerintah, maka pada tingkat pertama Bundesrat melakukan kajian dan diskusi pada setiap rancangan undang-undang, sebelum nantinya rancangan undang-undang tersebut dibawa kepada Bundestag beserta pengantar dari Bundesrat dan penilaian dari pemerintah. Rancangan undang-undang yang disetujui oleh Bundestag kemudian dikritisi oleh Bundesrat dalam pembahasan tingkat kedua. Dan kesepakatan atau resolusi untuk rancangan undang-undang disetujui oleh suara terbanyak dalam sidang bersama dengan Bundestag.

Meski memiliki kewenangan untuk menyetujui dan mem-veto (menolak) suatu rancangan undang-undang, namun kekuatan Bundesrattidaksama dengan Bundestag. ${ }^{43}$ Sebab Basic Law telah menentukan rancangan undangundang mana saja yang diharuskan mendapat persetujuan Bundesrat, yaitu rancangan undang-undang untuk mengamandemen konstitusi, rancangan undang-undang yang berkaitan dengan pelaksanaan administrasi Lander, serta rancangan undang-undang yang mempengaruhi kondisi keuangan negara. ${ }^{44}$ Dalam rancangan undang-undang lainnya selain yang telah ditentukan Basic Law harus mendapat persetujuan Bundesrat, maka penolakan (veto) dari Bundesrat dapat dikalahkan (overriden) oleh Bundestag. ${ }^{45} \mathrm{Hal}$ ini disebabkan meski Bundesrat memiliki kewenangan untuk memveto rancangan undang-undang, tetapi fungsi utamanya adalah untuk mengajukan argumen baru dan argumen tambahan yang nantinya akan menghasilkan kesepakatan terbaik. ${ }^{46}$

Meskipun pada awalnya keberadaan Bundesrat oleh para perumus Basic Law tidak dimaksudkan untuk menjadi majelis tinggi yang setara dengan Bundestag, namun dalam prakteknya peran Bundesrat dalam proses legislasi nasional semakin berkembang hingga menjadisetara dengan Bundestag, sebagaimana hal itu dibuktikan dengan pernyataan David Conradt bahwa:

"Originally the framers of the Basic Law anticipated that only about 10 percent of all federal legislation would require Bundesrat approval and hence be subject to Bundesrat veto. In practice, however, through bargaining in the legal comittees in each house, and judicial interpretation, the scope of the Bundesrat absolute veto power has been enlarged to the point where it can now veto roughly 60 percent of all federal legislation. This unforeseen development occured largely because many federal laws which refer to matters not subject to veto nonetheless contain provisions that set forth how the states are to administer and implement the legislation. Citing Article 84 of

42 Arthur Gunlicks, Op. Cit, hlm. 347.

43 Frank Feulner, Op. Cit, Hlm. 30.

44 Penolakan (veto) dari Bundesrat terhadap rancangan undang-undang yang telah ditentukan oleh Basic Law harus mendapatkan persetujuan Bundesrat dikenal sebagai absolute veto, veto jenis ini tidak dapat dikalahkan oleh Bundestag.

45 Penolakan (veto) jenis ini dikenal sebagai suspensive veto, sebagaimana dikemukakan Arthur Gunlicks: "If the veto represents a majority of the Bundesrat, i.e., at least 35 of 69 votes, it can be overridden by an absolute majority vote of the Bundesrat. But if the suspensive veto represents a two-thirds majority of the Bundesrat, i.e., 46 votes, the Bundestag can override only by a two-thirds vote" Lebih jelasnya lihat Arthur Gunlicks, Op. Cit, hlm. 349.

46 Frank Feulner, Op. Cit, hlm. 31. 
the Basic Law, the states have argued that, since they are instructed as to how the federal legislation is to be administered, the legislation, in both its substantive and procedural aspects, require Bundesrat approval." ${ }^{\prime 47}$

Akibat dari semakin kuatnya peran Bundesrat tersebut, pada akhirnya justru banyak memunculkan krtik dan kekecewaan terutama dari partai-partai politik yang menguasai suara mayoritas di Bundestag. Kritik dan kekecewaan terhadap Bundesrat tersebut pada dasarnya dilandasi oleh beberapa alasan:

Pertama, terjadinya pergeseran paradigma mengenai pandangan federalisme kooperatif yang dianut Jerman. Dimana pandangan tersebut dicerminkan oleh peran Bundesrat untuk memberi persetujuan terhadap suatu rancangan undang-undang federal. Dalam perkembangannya saat ini di Jerman, pandangan tersebut justru dianggap membuat lambatnya pembuatan suatu kebijakan (slower decision making), berkurangnya transparansi dalam pembuatan kebijakan, serta semakin meningkatnya lobby-lobby politik dalam pembuatan suatu kebijakan, yang menyebabkan semakin sulitnya rakyat mengetahui siapa yang bertanggungjawabatassuatu kebijakan. ${ }^{48}$ Kedua, keikutsertaan secara langsung pemerintah Lander dalam proses legislasi federal melalui Bundesrat cenderung makin mengaburkan pentingnya isu-isu mengenai Lander di pemilu Lander, dan justru merubah pemilu Lander menjadi pemilu untuk duduk di majelis tinggi. Ketiga, dalam praktiknya peran Bundesrat justru tidak digunakan untuk mengakomodir kepentingan dari Lander melainkan untuk kepentingan partai politik, hal ini terjadi ketika mayoritas representasi Lander di Bundesrat berasal dari partai oposisi pemerintah federal. ${ }^{49}$

Akibat dari kritik dan kekecewaan tersebut pada akhirnya menyebabkan pada tahun 2006 diadakan reformasi atau amandemen terhadap ketentuan mengenai federalisme yang terdapat dalam Konstitusi Jerman, dimana reformasi tersebut dimaksudkan untuk mengurangi peran Bundesrat yang amat besar dalam proses legislasi federal dengan memberikan kewenangan legislasi yang lebih besar terhadap Lander, serta menambahkan ketentuan baru dalam ranah prosedur administratif. ${ }^{50}$ Reformasi tersebut dapat dilihat dalam Article 84 (1) Basic Law dimana ketentuan dalam Article tersebut sebelum amandemen mengatur bahwa pembentukan undang-undang federal yang substansinya mempengaruhi pelaksanaan administrasi dari pemerintahan Lander mengharuskan adanya persetujuan dari Bundesrat terlebih dahulu, dan pemerintah Lander tidak diperbolehkan membuat aturan pelaksana atau undangundang Lander yang menyimpang dari ketentuan undang-undang federal yang telah mendapat persetujuan Bundesrat tersebut, pasca amandemen ketentuan tentang keharusan adanya persetujuan Bundesrat terhadap setiap rancangan undang-undang federal yang substansinya mempengaruhi pelaksanaan administrasi Lander tersebut

Dalam Donald P. Kommers, Op. Cit, hlm. 101.

48 Greg Taylor, "Upper House Reform in Germany: the Comission for the Modernization of the Federal System", Constitutional Forum Constitutionnel, Volume 17, Number 1 (2008), hlm. 27 ,http://ssrn.com/abstract=no.1599438 (Diakses 10 April 2015).

$49 \quad$ Ibid, hlm. 28.

50 Konrad Reuter, Op. Cit, hlm. 40. 
dihapuskan dan memperbolehkan Lander membuat undang-undang Lander yang bertentangan dengan undang-undang federal, ${ }^{51}$ solusi tersebut diharapkan dapat mengurangi pengaruh Bundesrat serta meningkatkan keberagaman dan kompetisi diantara masingmasing Lander. ${ }^{52}$ Memang amandemen tersebut terbukti mengurangi penggunaan persetujuan (absolute veto) Bundesrat terhadap rancangan undang-undang federal, dimana sebelum tahun 2006 hampir 60\% rancangan undangundang federal membutuhkan persetujuan Bundesrat, setahun setelah amandemen terjadi pengurangan dimana hanya $42,7 \%$ rancangan undang-undang federal saja yang membutuhkan persetujuan dari Bundesrat. ${ }^{53}$ Meskipun berhasil mengurangi peran Bundesrat, namun tetap saja fungsi legislasi Bundesrat di Jerman masih dapat dikatakan kuat karena kemampuannya untuk ikut serta dalam seluruh proses legislasi.

\section{Perbandingan Fungsi Legislasi DPD dengan Bundesrat}

Dari penjelasan di atas maka membandingkan DPD di Indonesia dengan Bundesrat di Jerman sebagai majelis tinggi maka terdapat persamaan dimana keduanya sama- sama dibentuk untuk mencerminkan prinsip representasi daerah (regional representation) dalam proses pembentukan kebijakan di tingkat nasional, yaitu DPD mewakili provinsi di Indonesia sedangkan Bundesrat mewakili Lander di Jerman. Akan tetapi meski samasama dibentuk untuk mencerminkan prinsip representasi daerah, dalam prakteknya justru Bundesrat lah yang mampu mengintegrasikan prinsip tersebut karena memiliki kewenangan yang kuat untuk turut serta dalam seluruh proses legislasi di tingkat nasional, sebaliknya DPD justru tidak memiliki kewenangan yang kuat untuk ikut serta dalam menjalankan proses legislasi. Padahal apabila ditinjau dari segi keanggotaannya, dimana keanggotaan DPD diisi melalui pemilihan secara langsung oleh rakyat di tiap-tiap provinsi, sedangkan keanggotaan dari Bundesrat tidak diisi melalui pemilihan secara langsung oleh rakyat dari tiap Lander maka seharusnya DPD memiliki peran yang lebih besar dalam menjalankan fungsi legislasi yang dimilikinya sebagai majelis tinggi dibandingkan dengan Bundesrat, sebab sebagaimana dinyatakan oleh Arend Lijphart: ${ }^{54}$

"The actual political importance of second chambers (upper house) depends not only on 
their formal constitutional powers but also on their method of selection... Second chambers that are not directly elected lack the democratic legitimation."

Selain itu alasan lainnya mengapa fungsi legislasi yang dimiliki DPD seharusnya lebih kuat dibandingkan Bundesrat disebabkan Indonesia menganut sistem pemerintahan presidensil, sedangkan Jerman menganut sistem pemerintahan parlementer, sebagaimana dikatakan oleh Wheare dalam karya klasiknya yang berjudul "Legislatures" sistem pemerintahan yang dianut suatu negara amat mempengaruhi hubungan antara kedua kamar dalam sistem perwakilan bikameral, menurutnya negara yang tidak menganut sistem pemerintahan parlementer atau cabinet government cenderung memiliki majelis tinggi dengan kekuatan yang setara dengan majelis rendah, ${ }^{55}$ sebab dalam sistem parlementer (cabinet government), kabinet (eksekutif) hanya dapat bertanggungjawab kepada satu kamar saja, dan tanggungjawab tersebut sudah pasti kepada majelis rendah atau kamar yang dipilih secara langsung berdasarkan populasi sehingga lazimnya majelis rendah memiliki peran yang lebih dominan dalam proses legislasi. ${ }^{56}$ Berbeda dengan itu dalam sistem presidensilyang didasari oleh konsep pemisahan kekuasaan (separation of powers) karena adanya pemisahan antara eksekutif dan legislatif sudah seharusnya fungsi legislasi menjadi mutlak dimiliki oleh lembaga legislatif saja baik itu majelis tinggi atau majelis rendah, keterlibatan dari eksekutif hanya sebatas mengajukan rancangan undang-undang dan mengajukan hak veto saja, namun di Indonesia terdapat keganjilan karena Presiden sebagai eksekutif memiliki kewenangan untuk membahas dan terlibat dalam pengambilan keputusan untuk undang-undang bersama dengan DPR sebagai majelis rendah, sedangkan DPD sebagai majelis tinggi yang mewakili suara rakyat di daerah tidak memiliki hak untuk itu. ${ }^{57}$

Berdasarkan alasan-alasan tersebut maka dapat dikatakan bahwa meski keanggotaan dari anggota DPD memiliki legitimasi demokratis yang lebih besar dibandingkan Bundesrat, serta didukung oleh sistem pemerintahan yang cenderung memperkuat kedudukannya sebagai majelis tinggi, dalam kenyataannya justru Bundesrat lah yang benar-benar berhasil menjalankan fungsinya sebagai representasi teritorial dalam proses legislasi, begitu kuatnya peran Bundesrat dalam proses legislasi tersebut membuat Lijphart mendeskripsikannya sebagai "one of the most powerful upper chambers in the world". 58

Seperti yang dikemukakan oleh Hansko Broeksteeg dalam sistem perwakilan bikameral majelis tinggi atau kamar kedua memiliki dua peran dalam menjalankan fungsi legislasi yaitu "rivalry" dan "assistance". "Rivalry" memiliki arti apabila majelis tinggi memiliki peran atau kekuatan yang sama dalam pembentukan

55 Dalam pendapatnya tersebut Wheare mencontohkan Senate di Amerika Serikat dan Council of States di Swiss sebagai majelis tinggi yang memiliki kekuatan yang setara dalam fungsi legislasi dengan majelis rendahnya, kedua negara tersebut tidak menganut sistem pemerintahan parlementer. Lebih jelasnya lihat K.C. Wheare, Op. Cit, hlm. 204.

56 Ibid, hlm. 201.

57 Enny Nurbaningsih, "Implikasi Putusan Mahkamah Konstitusi Nomor 92/PUU-X/2012 dan Alternatif Model Hubungan Kelembagaan Terkait Pembentukan Undang-Undang”, Jurnal Mimbar Hukum, Vol. 27, Nomor 1, Februari (2015), hlm. 2.

$58 \quad$ Arend Lijphart, Op. Cit, hlm. 98. 
kebijakan dengan majelis rendah. Sedangkan "assistence" memiliki arti apabila majelis tinggi memiliki fungsi legislasi yang lebih lemah dan peranannya hanyalah untuk membantu majelis rendah seperti mengoreksi dan memberi pertimbangan dalam membentuk undangundang. ${ }^{59}$ Dan melihat lemahnya fungsi legislasi yang dimiliki oleh DPD di Indonesia karena secara konstitusional kewenangannya yang terbatas hanya sekedar mengajukan, membahas, dan mengawasi RUU tertentu, tidak sampai pada memutuskan apakah suatu RUU dapat menjadi UU, maka dapat dikatakan bahwa fungsi legislasi yang dimiliki DPD pun paling jauh hanya sampai kepada peran "assistence". Sebaliknya Bundesrat di Jerman, meski kewenangannya sedikit dikurangi pada saat dilakukannya amandemen terhadap Basic Law di tahun 2006, namun tetap memiliki kewenangan yang kuat dalam menjalankan fungsi legislasi karena tetap dapat mengajukan rancangan undang-undang serta memveto suatu rancangan undang-undang yang diajukan oleh pemerintah atau majelis rendah, sehingga perannya dalam fungsi legislasi dapat dikatakan bersifat "effective rivalry" sekaligus "effective assistance" ${ }^{\prime \prime}$.

Sebagaimana dijelaskan oleh Lijphart, bahwa pada umumnya sistem bikameral terklasifikasi menjadi dua tipe yakni strong bicameral (bikameral kuat) dan weak bicameral (bikameral lemah). ${ }^{61}$ Tipe strong bicameral terjadi dalam dua kondisi yaitu jika kekuasaan masing-masing kamar relatif seimbang dalam menjalankan fungsilegislasi dan komposisi kedua kamar terdiri dari perwakilan yang berbeda. ${ }^{62}$ Sedangkan suatu sistem perwakilan dianggap sebagai weak bicameral apabila kekuasaan antara kedua kamar tidak seimbang, serta komposisi perwakilan dan cara pengisiannya sama. ${ }^{63}$ Maka dari itu dari perannya dalam menjalankan fungsi legislasi yang bersifat effective rivalry sekaligus effective assistance tersebut, serta komposisi keanggotaannya yang berbeda dapat dikatakan bahwa Jerman menganut sistem bikameral dengan tipe strong bicameral, sedangkan Indonesia menganut sistem bikameral dengan tipe weak bicameral karena lemahnya fungsi legislasi yang dimiliki oleh DPD.

Oleh karena itu melihat bahwa fungsi legislasi dari Bundesrat dan DPD yang berbanding terbalik tersebut maka dapat dikatakan bahwa keberadaan kedua majelis tersebut dalam sistem bikameral merupakan contoh yang unik dan tidak lazim, sebab DPD sebagaimana dikemukakan oleh Sherlock bahwa "is thus a quite example of a second chamber because it represents the odd combination of limited powers and high legitimacy" yang mana kombinasi tersebut menurutnya tidak ditemukan dimanapun di dunia. ${ }^{64}$ Sebaliknya 
Bundesrat juga merupakan contoh yang tidak lazim karena memiliki legitimasi yang rendah namun memiliki peran yang kuat dalam fungsi legislasi.

\section{Penutup}

Berdasarkan pembahasan di atas, tampak bahwa peran DPD di Indonesia dengan Bundesrat di Jerman dalam menjalankan fungsi legislasi amatlah berbanding terbalik. Dimana terlihat bahwa peran DPD sebagai majelis tinggi dalam menjalankan fungsi legislasi paling jauh hanya sebatas memberikan "assistance" bagi DPR sebagai majelis rendah. Sedangkan Bundesrat sebagai majelis tinggi dalam perannya menjalankan fungsi legislasi tidak hanya bersifat "effective assistance" tetapi sekaligus sebagai "effective rivalry" bagi Bundestag yang merupakan majelis rendah karena kemampuannya untuk ikut serta dalam seluruh proses legislasi. Padahal apabila ditilik dari mekanisme pengisian jabatannya serta sistem pemerintahan yang terdapat di Indonesia, sudah seharusnya DPD memiliki fungsi legislasi yang jauh lebih kuat dibandingkan dengan Bundesrat sebab memiliki mekanisme pengisian jabatan yang lebih demokratis serta sistem pemerintahan yang lebih mendukung agar DPD memiliki fungsi legislasi yang kuat.

Maka dari itu agar dinamika politik legislasi di tingkat nasional di Indonesia tidak lagi mengutamakan kepentingan politik semata dan meminggirkan kepentingan daerah, maka diperlukan amandemen kelima terhadap UUD 1945 untuk memperkuat kewenangan konstitusional DPD dalam melakukan fungsi legislasi, agar nantinya DPD sesuai dengan gagasan yang dicita-citakan ketika dibentuknya mampu menjadi suatu lembaga yang dapat mengintegrasikan kepentingan daerah di tingkat nasional.

\section{Daftar Pustaka}

\section{Buku}

Asshiddiqie, Jimly, Perkembangan dan Konsolidasi Lembaga Negara Pasca Reformasi, (Jakarta: Sekjen dan Kepaniteraan Mahkamah Konstitusi Republik Indonesia, 2006)

Ball, Alan R.,Modern Politics and Government (Fourth Edition), (London: Macmillan Education, 1988)

Fajrul Falakh, Mohammad, "Susunan dan Kedudukan DPD", dalam DPD dalam Sistem Ketatanegaraan Republik Indonesia, disusun oleh Janedri M. Gaffar dkk (eds), (Jakarta: Sekertariat Jenderal MPR, 2003)

Gunlicks, Arthur, The Lander and German Federalism, (Manchester and New York: Manchester University Press, 2003)

Isra, Saldi, Pergeseran Fungsi Legislasi (Menguatnya Model Legislasi Parlementer Dalam Sistem Presidensial Indonesia), (Jakarta: Rajawali Pers, 2013)

Kommers, Donald P., The Constitutional Jurisprudence of the Federal Republic of Germany, (Durham and London: Duke University Press, 1997)

Legowo, TA., "Keterwakilan Politik dan Tipe Parlemen dalam Perspektif Teoritis dan Sejarah", dalam Gagasan Amandemen UUD 1945 Suatu Rekomendasi, disusun oleh Mohammad Fajrul Falaakh (ed), (Jakarta: Komisi Hukum Nasional $\mathrm{RI}, 2008)$

Lijphart, Arend,Pattern of Majoritarian and Consensus Government in Twenty-One Country, (New Haven and London: Yale University Press, 1984)

Mahfud MD, Perdebatan Hukum Tata Negara Pasca Amandemen Konstitusi, (Jakarta: Rajawali Pers, 2011)

Manan, Bagir,Teori dan Politik Konstitusi, (Jakarta: FH UII Press, 2003)

Manan, Bagir dan Susi Dwi Harijanti, Memahami Konstitusi (Makna dan Aktualisasi), (Jakarta: Rajawali Pers, 2014)

Martin, Shane and Thomas Saalfeld (eds), The Oxford Handbook of Legislative Studies, (Oxford: Oxford University Press, 2014) 
Reuter, Konrad, The Bundesrat and The Federal System (14th Edition), (Berlin: Secretary General of The Bundesrat, 2009)

Soemitro, Ronni Hanitijo, Metode Penelitian Hukun dan Jurimetri, (Jakarta: Ghalia Indonesia, 1998)

Strong, C.F., Modern Political Constitutions, (London: Sidgwick \& Jackson, 1972)

Susanti, Bivitri et.al, Semua Harus Terwakili, Studi Mengenai Reposisi MPR, DPR, dan Lembaga Perwakilan di Indonesia, (Jakarta: Pusat Studi Hukum dan Kebijakan Indonesia, 2000)

Venter, Francois, Constitutional Comparison (Japan, Germany, Canada \& South Africa As Constitutional State), (Cape Town: Juta \& CO, 2000)

Wheare, K.C.,Legislatures, (London: Oxford University Press, 1963)

\section{Makalah/Artikel/Prosiding/Hasil Penelitian}

Broeksteeg, Hansko and Erik Knippenberg, "The Role of the Senate in the Legislative Process", Maastricht Journal of European and Comparative Law, Vol. 13, No. 2, (2006)

Feulner, Frank, "Menguatkan Demokrasi Perwakilan di Indonesia: Tinjauan Kritis Terhadap DPD", Jurnal Jentera, Edisi 8, Tahun III, Maret (2005)

Harijanti, Susi Dwi, "Reformasi Sistem Perwakilan Indonesia", Jurnal Konstitusi PSKN FH Universitas Padjadjaran, Volume I Nomor 1, November (2009)

Isra, Saldi The Role of the Second Chamber In the UK and Indonesia, (Makalah merupakan tugas akhir ketika mengikuti Short Course "What Democracy Means" di University of Birmingham UK, Januari-April 2006, diselenggarakan oleh Chevening Fellowship, UK)

Isra, Saldi, Merampas Daulat Rakyat, Kompas, 12 September 2014.
National Democratic Institute, One Chamber or Two? Deciding Between a Unicameral And Bicameral Legislature, (Legislative Research Series, Paper \#3, 1998)

Nurbaningsih, Enny, "Implikasi Putusan Mahkamah Konstitusi Nomor 92/PUU-X/2012 dan Alternatif Model Hubungan Kelembagaan Terkait Pembentukan UndangUndang", Jurnal Mimbar Hukum, Vol. 27, Nomor 1, Februari (2015)

Sherlock, Stephen, Indonesia's Regional Representative Assembly: Democracy, Representation and the Regions (A Report on the Dewan Perwakilan Daerah), (Canberra: Center for Democratic Institutions, 2005)

Waldron, Jeremy,Bicameralism, (Public Law \& Legal Theory Research Paper Series Working Paper No. 12-19, New York University School of Law, 2012).

\section{Internet}

Taylor, Greg, "Upper House Reform in Germany: the Comission for the Modernization of the Federal System", Constitutional Forum Constitutionnel, Vol 17, No 1, (2008), http://ssrn.com/ abstract=no.1599438 (Diakses 10 April 2015) http://www.hukumonline.com/berita/baca/ It543258707db2a/ini-isi-lengkap-perppu-pilkada-langsung (diakses pada 26 Juli 2015) http://www.bbc.com/indonesia/berita_indonesia/2015/01/150120_perppu_pilkada_sah (diakses pada 26 Juli 2015)

\section{Peraturan}

Undang-Undang Dasar Negara Republik Indonesia Tahun 1945

German Basic Law (The Constitution of the Federal Republic of Germany 1949) 